\title{
RELATIONSHIP BETWEEN ELDERLY BODY MASS INDEX AND MOTOR PERFORMANCE IN PEER GROUPS
}

\author{
Thalita Andrade Oliveira ${ }^{1}$, Stenio Fernando Pimentel Duarte ${ }^{2}$, Luciana Araújo do Reis ${ }^{3}$
}

\footnotetext{
${ }^{1}$ Graduate Physical Therapy student, Faculdade Independente do Nordeste (FAINOR). Vitória da Conquista, Bahia, Brazil. E-mail: thalytinha12@hotmail.com

${ }^{2}$ Doctoral student in Clinical Physiopathology, Universidade Federal do Rio de Janeiro. Professor, FAINOR. Vitória da Conquista, Bahia, Brazil. E-mail: steniofernando@gmail.com

${ }^{3}$ Ph.D. in Health Sciences. Professor, Universidade Estadual do Sudoeste da Bahia and FAINOR. Jequié, Bahia, Brazil. E-mail: lucianauesb@yahoo.com.br
}

\begin{abstract}
This analytical, cross-sectional and quantitative study aimed at investigating the relationship between body mass index and motor performance of elderly who participated in a peer group. The study site was a elderly' peer group that included 82 people, in the municipality of Vitória da Conquista-BA (Brazil). A statistically significant difference between the variables body mass index (above $27 \mathrm{~kg} / \mathrm{m}^{2}$ ) and limited balance ( $\mathrm{p}$-value $=0,008$ ), and between body mass index (above $27 \mathrm{~kg} / \mathrm{m}^{2}$ ) and limitation to squat and pick a pencil from the floor ( $\mathrm{p}$-value=0.004) was found by applying the Chi-square test. This study found that the body mass index $\left(\mathrm{above} 27 \mathrm{~kg} / \mathrm{m}^{2}\right)$ negatively influenced the following activities in the elderly: balance and squat to pick up a pencil from the floor.
\end{abstract}

DESCRIPTORS: Ageing. Weight. Functionality.

\section{RELAÇÃO ENTRE ÍNDICE DE MASSA CORPORAL E DESEMPENHO MOTOR DE IDOSOS PERTENCENTES A GRUPOS DE CONVIVÊNCIA}

RESUMO: O estudo teve como objetivo verificar a relação entre índice de massa corporal e desempenho motor de idosos participantes de grupo de convivência. Trata-se de uma pesquisa do tipo analítica com delineamento transversal e abordagem quantitativa. O local de estudo foi um grupo de convivência de idosos, do município de Vitória da Conquista-BA (Brasil) com amostra de 82 idosos. Com a aplicação do teste qui-quadrado, constatou-se diferença estatística significativa entre as variáveis indice de massa corporal (acima de $27 \mathrm{~kg} / \mathrm{m} 2)$ e limitação do equilíbrio ( $\mathrm{p}$-valor=0,008), e entre índice de massa corporal (acima de $27 \mathrm{~kg} / \mathrm{m} 2$ ) e limitação da atividade de agachar e pegar um lápis no chão ( $p$-valor=0,004). Verificou-se que o indice de massa corporal (acima de $27 \mathrm{~kg} / \mathrm{m} 2$ ) influencia de maneira negativa nas atividades de equilíbrio e agachar e pegar um lápis no chão dos idosos avaliados.

DESCRITORES: Envelhecimento. Peso. Funcionalidade.

\section{RELACIÓN ENTRE EL ÍNDICE DE MASA CORPORAL Y EL DESEMPEÑO MOTOR EN ANCIANOS QUE PERTENECEN A GRUPOS DE CONVIVENCIA}

RESUMEN: El estudio objetivó verificar la relación entre el indice de masa corporal y el rendimiento motor de ancianos que participan de un grupo de convivencia. Se trata de una investigación de tipo analítica con diseño transversal y enfoque cuantitativo. El contexto de estudio fue un grupo de convivencia de ancianos, en la ciudad de Vitória da Conquista-BA, (Brasil) con una muestra de 82 ancianos. Con la aplicación de la prueba de Chi-cuadrado, se constató una diferencia estadísticamente significativa entre las variables indice de masa corporal (más de $27 \mathrm{~kg} / \mathrm{m} 2$ ) y limitación de equilibrio (p-valor=0,008), y entre indice de masa corporal (más de $27 \mathrm{~kg} / \mathrm{m} 2$ ) y limitación de la actividad de agacharse y recoger un lápiz del suelo ( $\mathrm{p}$-valor=0,004). En esta perspectiva, en el presente estudio, se verificó que el indice de masa corporal (más de $27 \mathrm{~kg} / \mathrm{m} 2$ ) afecta negativamente las actividades de equilibrio y de agacharse y recoger un lápiz en el suelo entre los ancianos evaluados.

DESCRIPTORES: Envejecimiento. Peso. Funcionalidad. 


\section{INTRODUCTION}

The elderly population has been growing in an accelerated and progressive rhythm, both in developed and in developing countries. The Brazilian population is also ageing and within 65 years it will move from the $16^{\text {th }}$ to the $6^{\text {th }}$ position in the world rank. ${ }^{1}$

Ageing is a natural process that is characterized by the progressive reduction of the organic functional reserve and by physical, psychological and social changes that vary from individual to individual. It occurs gradually for some and quickly for others. ${ }^{2}$ This process depends not only on our genetic condition but also on the habits we acquire during our lives, such as diet and physical activity. Inappropriate habits and sedentarism will significantly contribute towards the increase of chronic diseases and incapacities. ${ }^{2}$

In old age, obesity is associated to multifactorial diseases and is defined by the excess of fat tissue. It arises from dietary excess, sedentarism, genetic, metabolic, social cultural and psychosocial factors. ${ }^{2}$ A person is considered obese when her body mass index (BMI) is equal to or greater than $30 \mathrm{~kg} / \mathrm{m}^{2}$. It is important to include an evaluation of the BMI with the elderly person's overall health conditions, especially with regard to obesity, which generates difficulties to move and perform tasks such as the activities of daily living (ADLs) and instrumental activities of daily living (IADLs).

Obesity has functional repercussions on the elderly, and can lead to a reduction of their physical abilities, associated to the ageing process. Motor performance impairment is related to mobility and is greater in obese and overweight elders than in those with normal BMI. Functional impairment and a reduction of physiological reserves will affect the systems and cause a process of fragility that is associated with loss of autonomy, reduced quality of life and increased mortality. ${ }^{5}$

According to research performed by the World Health Organization (WHO) in 2002, ${ }^{6}$ obesity is a global epidemics and is among the ten major risks for human health. Obesity affects health, psychological well-being, longevity and quality of life (QL). ${ }^{7}$ It increases the risk of mortality and worsens the QL indicators in groups of elderly people. Excess body fat can give rise to cardiovascular, renal and digestive diseases, diabetes mellitus, kidney and orthopedic diseases and reduce motor performance. ${ }^{8}$

Decreased motor performance is evident with age progression and may be linked to the ageing process, degenerative pathologies, lifestyle or a combination of these factors. The ability to perform known functions such as the activities of daily living (ADLs) and the instrumental activities of daily living (IADLs) requires motor abilities related to strength, flexibility, aerobic capacity and balance; and the cognitive actions are related to executive functions, attention and memory.

The reduction of motor performance is frequently associated to the risk of incapacity and worse quality of life that leads to the loss of independence and autonomy to perform the activities of daily living and compromises the elderly person's quality of life. $^{5}$

Since there are a limited number of studies that discuss the relationship between obesity in old age and impaired motor performance, this study aimed at analyzing the relationship between body mass index and motor performance of senior citizens who participate in a peer group.

\section{METHOD}

This is an analytical, cross-section and quantitative study. The study site was an elderly peer group, in the municipality of Vitória da ConquistaBA (Brazil), in the Southeastern region of the state of Bahia. Created in 1997, the group received 150 elders in 2014. The aim of the peer group is to value the elder through activities in a crafts shop, literacy classes, dance workshops, events and tours, and medical care.

The study population consisted of 150 senior citizens. Out of these, 68 were excluded (15 were on wheelchairs, 17 used a walking cane, nine had visual impairment, five had hearing impairment, 22 did not attend the group during the data collection, and 15 did not present mental conditions to respond to the research tool). The study sample, therefore consisted of 82 senior citizens.

The study inclusion criteria were the following: have preserved mental condition (score over 24 points), as evaluated by the Mini Mental State Exam (MMSE), and be able to walk without support. The 
exclusion criteria were the following: not participate in the group during the data collection period and present hearing or visual impairment.

Data were collected from January to April 2014. The research tool was formed by six parts, as follows:

Part 1 - Cognitive assessment using the MMSE, a very useful tool to detect the cognitive deficits in the elderly. It comprises ten questions that assess short- and long-term memory, orientation, information on daily routine and ability to calculate. It is possible to know whether the individual is able to participate in the rest of the rest of the study by the answers given to the MMSE.

Part 2 - Sociodemographic information: assessed using a questionnaire including the following items: sex (male or female), age (collected as completed years), marital status (no companion, married/living together/dating, single, separated/legally separated/divorced, widowed, does not know/did not answer), type of income, education (collected as years of study completed) and profession.

Part 3 - Health condition, which evaluated the following: presence and type of health problems; presence and type of sequelae, undergone treatment, drug use and self-perception regarding health status.

Part 4 - Functional capacity (FC): activities of daily living (Barthel Index) and instrumental activities of daily living (Lawton Scale). The Barthel index is used to assess functional capacity and is formed by ten activities: feeding, bathing, personal hygiene, dressing, intestines, bladder, transferring for intimate hygiene, transferring - chair and bed, walking and climbing stairs. The score corresponds to the sum of all the points obtained and is considered no matter if the individual reaches the total score of 100 points. Scores less than 50 indicate dependence for the ADLs. ${ }^{10}$ The Lawton Scale is used to assess FC, and includes more the complex activities required for a more autonomous social life, such as making phone calls, going shopping, preparing meals, organizing the house or gardening, fixing the house, doing the washing and the ironing, using transport, using medication and controlling the private and/or home finances. For each question, the first answer means independence, the second means partial dependence or capacity with support, and the third means dependence. The maximum score is $27 .{ }^{11}$

Part 5 - Motor performance assessment: this uses the flexibility/mobility tests, the sit-stand test (SST), the $2.44 \mathrm{~m}$ walking test, balance and hand grip strength.

Flexibility/Mobility: the "squat and pick a pencil from the floor" test was proposed to observe the flexibility / mobility of the posterior leg muscles and to verify the elder's capacity of squatting and standing up. The individual would stand with both feet together, then squat and pick up a pencil $30 \mathrm{~cm}$ in front of his feet. He would return to the standing position within 30 seconds. The observation was whether the individual completed the test. If he did, how long it took him to complete it. ${ }^{12}$

Sit and Stand Test (SST): this test was used to measure the strength of elder's lower limbs. The individual would start the test seated, with his back straight and arms crossed over his chest, his feet as wide as his shoulder width and completely on the ground. One of the feet should be slightly ahead of the other for balance. The individual would stand up and sit five times as quickly as possible, with no pauses. The test was successful when performed in 60 seconds or less. ${ }^{12}$

Walking test $-2.44 \mathrm{~m}$ : used to assess physical mobility, velocity, agility and dynamic balance. The individual would walk on the trajectory marked on the ground (2.44 m), at his normal speed, as if walking on the street. It was verified whether he could perform the test and how long it took him on the first and second times (in seconds).

Balance: used to assess static balance. The individual would initially stand for 10 seconds with his feet together and eyes open. He would then stand up for 10 seconds and place one heel in front of the other, keeping his eyes open. Next, the individual would remain standing and support himself on the other leg for 10 seconds without any type of support. Finally, the individual would remain standing up supporting himself on the opposite leg for 10 seconds without any type of support. The individual was classified as incapable if he could not perform any of the tasks; weak if he was unable to perform task 1 only, average if he was able to perform only tasks 1 and 2, and good if he was able to perform only tasks 1 and 2 plus task 3 and or $4 .^{12}$ 
Hand grip strength (HGS): this was assessed using a manual hydraulic dynamometer (SAEHAN model SH500). The device was adjusted to each individual's hand size. Three measurements were taken from the left and right arm of the participants, alternated per segment. For each measurement, the individual was seated with his shoulder in a neutral position, elbow at $90^{\circ}$, forearm in neutral position and wrist between 0 and $30^{\circ}$ extension and 0 to $15^{\circ}$ ulnar deviation. The individual gripped the dynamometer with the strength of his hand. At the end, the strength was registered in kilogram/force $(\mathrm{kg} / \mathrm{f})$. Three attempts were made with a recovery period of one minute between them. The average of the three attempts is the HGS value. ${ }^{12}$ Senior citizens submitted to surgery in the arm or hand within three months prior to data collection were excluded from the test.

Part 6 - Anthropometric data assessment. The BMI data were obtained using a portable digital electronic scale. The individual was barefoot and wearing the least clothing possible. The height was measured using an anthropometer fixed to a portable dismountable aluminum support. The body mass was obtained in kilograms $(\mathrm{Kg})$ and the height in meters $(\mathrm{m})$. The body mass was divided by the square of the height to obtain the BMI $(\mathrm{Kg} /$ $\mathrm{m}^{2}$ ). Low weight is equal to a BMI score $<18.5 \mathrm{~kg} /$ $\mathrm{m}^{2}$; well nourished or adequate was equal to BMI $\geq 18.5 \mathrm{~kg} / \mathrm{m}^{2}-24.9 \mathrm{~kg} / \mathrm{m}^{2}$; overweight was equal to $\mathrm{BMI} \geq 25 \mathrm{~kg} / \mathrm{m}^{2}-29.9 \mathrm{~kg} / \mathrm{m}^{2}$; and obese was equal to $\mathrm{BMI} \geq 30 \mathrm{~kg} / \mathrm{m}^{2} .^{13}$

The quantitative variables were presented as average, standard deviation, minimum and maximum values while the categorical variables were calculated as frequencies and percentages. The Chisquare test was applied to verify the relationship between body mass index and motor performance, with a 5\% significance level. The data were tabulated and analyzed using the Statistical Package for the Social Sciences for Windows (SPSS, version 20.0).

The project was approved by the Ethical Research Committee for involving Human Beings of the Universidade Estadual do Sudoeste da Bahia (Opinion N. 177/2011), in accordance with the ethical norms established by Resolution no. 466, 2012 Brazilian National Board of Health, and included obtaining a signed Informed Consent Form from each participant.

\section{RESULTS}

This study observed a greater distribution of female senior citizens $(92.7 \%)$, aged 60 years or older $(53.7 \%)$, with income equal to or less than a minimum wage $(74.4 \%)$, originating from a pension $(47.6 \%)$, widow $(37.8 \%)$ and homemaker $(74.4 \%)$.

Table 1 - Sociodemographic characteristics of the elderly participating in a peer group. Vitória da Conquista-BA, Brazil, 2014

\begin{tabular}{lrr}
\hline Sociodemographic characteristics & $\mathbf{n}$ & $\%$ \\
\hline Sex & 76 & 92.7 \\
Female & 6 & 7.3 \\
Male & & \\
Age range & 44 & 53.7 \\
$\geq 68$ years & 38 & 46.3 \\
< 68 years & & \\
Income & 61 & 74.4 \\
$\leq 1$ Minimum wage & 21 & 25.6 \\
$>1$ Minimum wage & & \\
Income type & 17 & 20.7 \\
Retirement pension & 39 & 47.6 \\
Pension & 16 & 19.5 \\
Retirement pension and pension & 10 & 12.2 \\
Other & & \\
Marital status & 29 & 35.4 \\
Married/Common-law marriage & 12 & 14.6 \\
Single & 31 & 37.8 \\
Widow/Widower & 10 & 12.2 \\
\hline Separated/Legally Separated/Divorced & $\mathbf{8 2}$ & $\mathbf{1 0 0 . 0}$ \\
\hline Total & &
\end{tabular}

The assessment of health conditions showed there was a greater frequency of senior citizens who had illnesses $(80.5 \%)$, preserved cognitive functions $(76.8 \%)$, were independent for the activities of daily living $(87.8 \%)$ and dependent for the instrumental activities of daily living (75.6\%), felt pain $(63.4 \%)$ and perceived their health was good in comparison with other people their age (35.4\%). A total $74.5 \%$ of the senior citizens assessed their health positively. 
Table 2 - Health conditions of the elderly participating in a peer group. Vitória da ConquistaBA, Brazil, 2014

\begin{tabular}{lrr}
\hline & $\mathbf{n}$ & $\%$ \\
\hline Presence of illness & & \\
Yes & 66 & 80.5 \\
No & 16 & 19.5 \\
Mini mental state exam & & \\
Preserved cognitive function & 63 & 76.8 \\
Cognitive abnormality not suggestive of & & \\
deficit & 19 & 23.2 \\
Basic activities of daily living & & \\
Independent & 72 & 87.8 \\
Dependent & 10 & 12.2 \\
Instrumental activities of daily living & & \\
Independent & 20 & 24.4 \\
Dependent & 62 & 75.6 \\
Presence of pain & & \\
Yes & 52 & 63.4 \\
No & 30 & 36.6 \\
Self perception of health & & \\
Excellent & 14 & 17.0 \\
Very good & 18 & 22.0 \\
Good & 29 & 35.4 \\
Reasonable & 15 & 18.3 \\
Poor & 6 & 7.3 \\
\hline Total & $\mathbf{8 2}$ & $\mathbf{1 0 0 . 0}$ \\
\hline & &
\end{tabular}

The assessment of motor performance showed greater predominance of senior citizens with limited ability to squat and pick a pencil from the floor $(85.4 \%)$, no limitation for the sit and stand activity $(92.7 \%)$, no limitation in the walking test $(96.3 \%)$, no limitation in the hand grip strength $(79.3 \%)$ and no limitation in the balance activity $(81.7 \%)$.
Table 3 - Distribution of senior citizens according to motor performance activities. Vitória da Conquista-BA, Brazil, 2014

\begin{tabular}{lrr}
\hline & $\mathbf{n}$ & $\%$ \\
\hline Squat and pick a pencil from the floor & & \\
Limitation & 70 & 85.4 \\
No limitation & 12 & 14.6 \\
Sit/stand & & \\
Limitation & 6 & 7.3 \\
No limitation & 76 & 92.7 \\
Walking test & & \\
Limitation & 3 & 3.7 \\
No limitation & 79 & 96.3 \\
Hand grip strength & & \\
Limitation & 17 & 20.7 \\
No limitation & 65 & 79.3 \\
Balance & & \\
Limitation & 15 & 18.3 \\
No limitation & 67 & 81.7 \\
\hline Total & $\mathbf{8 2}$ & $\mathbf{1 0 0 . 0}$ \\
\hline
\end{tabular}

Regarding BMI, there was greater frequency of overweight senior citizens (54.9\%), with BMI average of $25.54( \pm 9.23) \mathrm{kg}$.

Table 4 - senior citizen distribution according to the Body Mass Index. Vitória da Conquista-BA, Brazil, 2014

\begin{tabular}{lrr}
\hline Body Mass Index & n & \% \\
\hline Insufficient weight $\left(<22 \mathrm{~kg} / \mathrm{m}^{2}\right)$ & 6 & 7.3 \\
Adequate weight $\left(22-27 \mathrm{~kg} / \mathrm{m}^{2}\right)$ & 31 & 37.8 \\
Excess weight $\left(>27 \mathrm{~kg} / \mathrm{m}^{2}\right)$ & 45 & 54.9 \\
\hline Total & $\mathbf{8 2}$ & $\mathbf{1 0 0 . 0}$ \\
\hline
\end{tabular}

The application of the Chi-square test $\left(x^{2}\right)$ showed a statistically significant difference between the variables, BMI (over $27 \mathrm{~kg} / \mathrm{m}^{2}$ ) and balance limitation ( $\mathrm{p}$-value=0.008), and between BMI (over $27 \mathrm{~kg} / \mathrm{m}^{2}$ ) and limitation to squat and get a pencil from the floor ( $p$-value $=0.004)$. 
Table 5 - Distribution of senior citizens' BMI according to motor performance activities. Vitória da Conquista-BA, Brazil, 2014

\begin{tabular}{|c|c|c|c|c|c|c|c|}
\hline & & & Bod & Mass Ind & & & \\
\hline & Up to 2 & $/ \mathrm{m} 2$ & Over & $\mathrm{rg} / \mathrm{m} 2$ & & & \\
\hline & $\mathbf{n}$ & $\%$ & $\mathbf{n}$ & $\%$ & $\mathbf{n}$ & $\%$ & p-value \\
\hline Balance & & & & & & & \\
\hline Limitation & 2 & 5.6 & 13 & 28.3 & 15 & 18.3 & 0.008 \\
\hline No limitation & 34 & 94.4 & 33 & 71.3 & 67 & 81.7 & \\
\hline Squat and pick & & & & & & & \\
\hline Limitation & 34 & 94.4 & 36 & 78.3 & 70 & 85.4 & 0004 \\
\hline No limitation & 2 & 5.6 & 10 & 21.7 & 12 & 14.6 & 0.004 \\
\hline Sit and stand & & & & & & & \\
\hline Limitation & 2 & 5.6 & 4 & 8.7 & 6 & 7.3 & 0.588 \\
\hline No limitation & 34 & 94.4 & 42 & 91.3 & 76 & 92.7 & \\
\hline Walk & & & & & & & \\
\hline Limitation & - & - & 3 & 6.5 & 3 & 3.7 & 0.119 \\
\hline No limitation & 36 & 100.0 & 43 & 93.5 & 79 & 96.3 & \\
\hline Muscle strengt & & & & & & & \\
\hline Limitation & 6 & 16.7 & 11 & 23.9 & 17 & 20.7 & 0.422 \\
\hline No limitation & 30 & 83.3 & 35 & 76.1 & 65 & 79.3 & \\
\hline
\end{tabular}

\section{DISCUSSION}

This study investigated the changes related to the process of ageing regarding BMI and motor performance in active senior citizens. Women were predominant in the senior citizens' group. This corroborates the national studies that showed a marked phenomenon called feminization of the elderly population: in general, women have longer life expectancy than men for they are more active and more careful regarding health and self-care than men. ${ }^{14-15}$

Regarding age range, the distribution was equal to or greater than 68 years old, and widows were present. Given the higher life expectancy of women in Brazil, this data is similar to studies in which similar age ranges and marital status were observed. Women live on average eight years longer than men because they take more care of their health. ${ }^{15-16}$ Regarding the prevention and treatment of pathologies, women accept participation in groups that discuss the subject, including peer groups, better than men in their search for a better quality of life and social and psychological well-being. The greater presence of widows in this group can be explained due to a rise in women's life expectation.
Regarding income, a monthly income less than the minimum wage, which refers to the pension, was observed. The data are comparable with a study in which low income ( $\leq 1$ minimum wage) is related to increasing age - it is difficult to get a job and so the elderly person has to live off a pension from his relatives or from other types of pensions. This can be related to some types of pathologies that prevent this population from having productive lives and make them leave the work market early.

Regarding health conditions, the WHO definition of health ${ }^{7}$ states that health is not lack of disease but a situation of perfect physical, mental and social well-being. According to this perspective, the classification of health condition will vary from individual to individual and will not be defined only by the presence or absence of any pathology. In the study, most participants presented some type of pathology. However, they had a positive perception of their health condition and classified it as good. A study performed in Florianopolis-SC (Brazil) observed that senior citizens who participated in peer groups had a better view of their health status when compared to those who did not participate in a group. They are more active because they practice activities such as crafts, cultural and artistic activities, group animation techniques and dances held at the centers. ${ }^{14}$ 
Regarding the activities of daily living, most senior citizens in this study were classified as independent, corroborating a study which observed that the elderly had functional independence and performed the activities of daily living. ${ }^{17}$ In this study, this independence can be related to the social inclusion that is offered by the peer groups and to the stimulus the individual receives to become more autonomous in performing his ADLs.

Regarding the instrumental activities of daily living, it was observed that most senior citizens in this study were classified as dependent. These results are different from those found in a study performed in the municipality of CamaragibePE (Brazil). The factors that can define the senior citizens' dependence to perform the IADLs in this study can be related to changes in mobility that affect walking. This can limit the senior citizen from performing certain activities. Other changes resulting from the ageing process, such as visual and hearing abnormalities, also restrict them from performing more complex tasks ${ }^{18}$ but have not been analyzed here.

This study observed no functional limitation in relation to HGS, which is different from a study that showed a significant correlation between older age and muscle strength and the influence of increased BMI on flexibility. Therefore, no limitation to motor performance associated to the strength of upper limbs was observed in this study. ${ }^{19}$

The walking test is performed to quickly and simply evaluate the mobility, velocity and dynamic balance capacity the senior citizen has. ${ }^{20}$ This test is related to his capacity to perform daily life activities in an independent and confident manner, without fearing falls or other accidents related to mobility, velocity and dynamic balance deficits. In this study, most participants had no limitation to perform these tests, which matches the results of study ${ }^{20}$ this means that the reduced motor performance is negligible.

Physical skills are related to functional independence both for youngsters and for the elderly. However, senior citizens' abilities suffer a decline generated by the natural process of ageing or due to other factors ${ }^{21}$ such as abnormal BMI, which is an important indicator of the nutritional status of the elderly. In this study, there was a greater distribution of overweight elderly people, corroborating a study that observed that the average BMI value was greater than $27 \mathrm{~kg} / \mathrm{m}^{2}$. This is a concern that is directly related to a smaller functional capacity in active elderly people. ${ }^{22}$ Therefore, obesity and overweight are negative factors for any age range, and generate extremely important implications both for health and general well-being.

A significant statistical difference was observed between "squat to pick a pencil from the floor" and overweight, and between overweight and balance, similar to study, ${ }^{23}$ which showed that elderly people with increased BMI have a greater prevalence of low motor performance as the greater amount of fat tissue can generate an excessive load on the body. This factor causes limitations to movement and overloads the joints that will be used to perform the movements required for the "squat and pick a pencil" test and to maintain body balance. Since balance anomalies cause great impacts on the social life of the elderly, they can reduce their autonomy and lead to changes in their daily lives and health condition. Reduced balance is related to a greater risk of falls. ${ }^{24}$ Excess weight modifies the body's geometry, increasing the mass of the different segments and imposing functional limitations that result in the inability to perform basic everyday activities. Keeping thin been prevents the decline of motor ability whereas an increased BMI (obesity and overweight) generates a smaller amplitude of movement and causes functional biomechanical limitations and dependence for the activities of daily living.

This study had the following bias: it did not ask the elderly citizens about physical activity practice, the lack of which could be associated to overweight. Given the above, the association of motor performance tests, "squat to pick a pencil" and balance tests with overweight does not eliminate a possible association with other factors which were not studied or compared in this study and which may interfere in these senior citizens' motor performance.

\section{CONCLUSION}

This study observed that the BMI (over $27 \mathrm{~kg}$ / $\mathrm{m}^{2}$ ) negatively influences the balance and squat to pick a pencil from the floor activities on the evaluated senior citizens. The ageing process associated with increased BMI can generate reduced motor performance, which is related to mobility. The results are relevant for the caring of elderly people by the healthcare professionals, especially nurses and physical therapists, including preventive measures against overweight and motor performance impairment. 


\section{REFERENCES}

1. Baldoni AO, Pereira LRL. Oimpacto do envelhecimento populacional Brazileiro para o sistema de saúde sob a óptica da farmacoepidemiologia: uma revisão narrativa. Rev Ciênc Farm Básica Aplicada [Internet]. 2011 [cited 2014 May 10]; 32(3):313-21. Available from: http://www.unifal-mg.edu.br/cefal/sites/default/ files/Baldoni, \%20Pereira, \%202011.pdf

2. Cararolino JA, Soares ML, Cândido GA. Envelhecimento e cidadania: possibilidades de convivência no mundo contemporâneo. Qualit@s Rev Eletr [Internet]. 2011 [cited 2014 May 10]; 1(1). Available from: http://revista.uepb.edu.br/index. php/qualitas/article/viewFile/1182/597

3. Cavalcanti CL, Gonçalves MCR, Asciutti LSR, Cavalcanti AL. Envelhecimento e obesidade: um grande desafio no século XXI. Rev Bras Ciênc Saúde [Internet]. 2010 [cited 2014 May 10]; 14(2):87-92. Available from: http:// periodicos.ufpb.br/ojs/index. $\mathrm{php} / \mathrm{rbcs} /$ article/viewFile/7230/5318

4. Lucio A, Bezerra MJC, Sousa SA, Miranda MLJ. Características da capacidade funcional e sua relação com o IMC em idosas ingressantes em um programa de educação física. Rev Bras Ciênc Mov [Internet]. 2011 [cited 2014 May 10]; 19(2):13-8. Available from: http:/ / portalrevistas.ucb.br/index.php/RBCM/ article/view/2415/1894

5. Santos RR, Bicalho MAC, Mota P, Oliveira DR, Moraes EN. Obesidade em idosos. Rev Med Minas Gerais [Internet]. 2013 [cited 2014 May 10]; 23(23):64-73. Available from: http://rmmg.org/artigo/detalhes/12

6. World Health Organization, Food and Agriculture Organization. Expert consultation on diet, nutrition and the prevention of chronic diseases. Geneva $(\mathrm{CH})$ : WHO; 2002.

7. Tavares TB, Nunes SM, Santos MO. Obesidade e qualidade de vida: revisão da literatura. Rev Med Minas Gerais. 2010; 20(3):359-66.

8. Moraes JM, Caregnato RCA, Schneider DS. Quality of life before and after bariatric surgery. Acta Paul Enferm [Internet]. 2014 [cited 2014 May 10]; 27(2). Available from: http://dx.doi.org/10.1590/19820194201400028

9. Bertolucci PH, Brucki SM, Campacci SR, Juliano Y. O mini-exame do estado mental em uma população geral: impacto da escolaridade. Arq Neuropsiquiatr [Internet]. 1994 [cited 2014 May 10]; 52(1):1-7 Available from: http://www.scielo.br/pdf/anp/v52n1/01.pdf

10. Minosso JSM, Amendola F, Alvarenga MRM, Oliveira MAC. Validação, no Brazil, do Índice de Barthel em idosos atendidos em ambulatórios. Acta Paul Enferm [Internet]. 2010 [cited 2014 May 10]; 23(2). Available from: http://dx.doi.org/10.1590/S010321002010000200011

11. Lawton MP, Brody E. Assessment of older people: self-maintaining and instrumental activities of daily living. The Gerontologist [Internet].1969 [cited 2014 May 10]; 9(3):179-86. Available from: http://www. eurohex.eu/bibliography / pdf/Lawton_Gerontol_1969-1502121986/Lawton_Gerontol_1969.pdf

12. Batista FS, Gomes GAO, Neri AL. Relationship between lower-limb muscle strength and frailty among elderly people. Sao Paulo Med J [Internet]. 2012 [cited 2014 May 10]; 130(2):102-8. Available from: http://www.scielo.br/pdf/spmj/v130n2/06.pdf

13. Tribess S, Junior JSV; Petroski EL. Estado nutricional e percepção da imagem corporal de mulheres idosas residentes no nordeste do Brazil. Ciênc Saúde Coletiva [Internet]. 2010 [cited 2014 May 10]; 15(1):31-8. Available from: http://dx.doi.org/10.1590/S141381232010000100008

14. Benedetti TRB, Mazo GZ, Borges LJ. Condições de saúde e nível de atividade física em idosos participantes e não participantes de grupos de convivência de Florianópolis. Ciênc Saúde Coletiva [Internet]. 2012 [cited 2014 May 10]; 17(8):2087-093. Available from: http:/ /dx.doi.org/10.1590/S141381232012000800019

15. Leite MT, Winck MT, Hildebrandt LM, Kirchner RM, Silva LAA. Qualidade de vida e nível cognitivo de pessoas idosas participantes de grupos de convivência. Rev Bras Geriatr Gerontol [Internet]. 2012 [cited 2014 May 10]; 15(3). Available from: http:// dx.doi.org/10.1590/S1809-98232012000300009

16. Silva HO, Carvalho IMAD, Lima FEL, Rodrigues LV. Perfil epidemiológico de idosos frequentadores de grupos de convivência no município de Iguatu, Ceará. Rev Bras Geriatr Gerontol [Internet]. 2011 [cited 2014 May 10]; 14(1). Available from: http://dx.doi. org/10.1590/S1809-98232011000100013

17. Lenardt MH, Carneiro NHK, Albino J, Willig MH. Qualidade de vida de idoso fragilizado da atenção primária. Acta Paulista de Enfermagem [Internet]. 2014 [cited 2014 May 10]; 27(5):399-404. Available from: http:/ / www.scielo.br/pdf/ape/v27n5/ pt_1982-0194-ape-027-005-0399.pdf

18. Albuquerque AG, Oliveira GSM, Silva VL, Nascimento CB. Capacidade funcional e linguagem de idosos nãoparticipantes e participantes de grupos de intervenção multidisciplinar na atenção primária à saúde. Rev CEFAC [Internet]. 2012 [cited 2014 May 10]; 14(5):95262. Available from: http:/ / dx.doi.org/10.1590/S151618462012005000019

19. Silva NAS, Menezes TN, Melo RLP, Pedraza DF. Força de preensão manual e flexibilidade e suas relações com variáveis antropométricas em idosos. Rev Assoc Med Bras [Internet]. 2013 [cited 2014 May 10]; 59(2). Available from: http://www.sciencedirect.com/ science/article/pii/S0104423013000031

20. Pinheiro PA, Passos TODO, Coqueiro RS, Fernandes $\mathrm{MH}$, Barbosa AR. Desempenho motor de idosos do Nordeste Brazileiro: diferenças entre idade e sexo. Rev Esc Enferm USP [Internet]. 2013 [cited 2014 May 
10]; 47(1). Available from: http:// dx.doi.org/10.1590/ S0080-62342013000100016

21. Gonçalves LHT, Silva AH, Mazo GZ, Silva AH, Mazo GZ, Benedetti TRB, et al. O idoso institucionalizado: avaliação da capacidade funcional e aptidão física. Cad Saúde Pública [Internet]. 2010 [cited 2014 May 10]; 26(9):1738-46. Available from: http://dx.doi. org/10.1590/S0102-311X2010000900007

22. Rech CR, Cruz JLS, Araújo EDS, Kalinowski FG, Dellagrana RA. Associação entre aptidão funcional e excesso de peso em mulheres idosas. Motriz: Rev Educ Fis [Internet]. 2010 [cited 2014 May 10]; 6(2). Available from: http://www.revistamotricidade. com/arquivo/2010_vol6_n2/v6n2a06.pdf
23. Carneiro JAO, Almeida DS; Coelho KHC, Pfrimer K, Santos-Pontelli TEG, Carneiro AAO, et al. Influência da obesidade e da força de preensão palmar no equilíbrio postural estático de idosas ativas. Motriz: Rev Educ Fis [Internet]. 2012 [cited 2014 May 10]; 18(3):432-40. Available from: http://www.scielo.br/scielo.php?script $=$ sci $_{-}$ arttext\&pid=S1980-65742012000300003

24. Barbosa AR, Souza JMP, Lebrão ML, Marucci MFN. Estado nutricional e desempenho motor de idosos de São Paulo. Rev Assoc Med Bras [Internet]. 2007 [cited 2014 May 10]; 53(1) Available from: http://dx.doi. org/10.1590/S0104-42302007000100024 